\title{
Feed efficiency of Nellore cattle selected for postweaning weight ${ }^{1}$
}

\section{André Michel de Castilhos ${ }^{2}$, Renata Helena Branco ${ }^{3}$, Tatiana Lucila Sobrinho Corvino ${ }^{2}$, Alexander George Razook ${ }^{4}$, Sarah Figueiredo Martins Bonilha ${ }^{3}$, Leopoldo Andrade de Figueiredo ${ }^{3}$}

\author{
${ }^{1}$ Apoio FAPESP. \\ 2 Programa de pós-graduação em Zootecnia - Universidade Estadual Paulista - FMVZ/Unesp. \\ 3 Instituto de Zootecnia - Centro de Pesquisas em Pecuária de Corte. \\ ${ }^{4}$ Instituto de Zootecnia - Centro de Pesquisas em Pecuária de Corte. Bolsista do CNPq.
}

ABSTRACT - Two Nellore herds were compared, one selected for greater postweaning weight and the other, control, selected for average postweaning weight, to evaluate the effects of 29 years of selection on feed efficiency. Sixty Nellore males (41 selected and 19 control) averaging $205 \mathrm{~kg}$ and 267 days of age were evaluated in individual pens during performance test. Performance and dry matter intake were used to determine the following feed efficiency traits: feed conversion; residual feed intake; residual gain; partial growth efficiency; relative growth rate and Kleiber ratio. After the 112-day experimental period, control animals showed lower body weight when compared to selected animals, however, they did not differ for dry matter intake (\% of body weight), rib-eye area and fat thickness at the $12^{\text {th }}$ rib subcutaneous region and on the rump region. Dry matter intake (kg/day) and average daily weight gain from selected animals were, respectively, $19.4 \%$ and $26.4 \%$ higher than the control ones. The highest average daily weight gain by selected animals promoted significant improvement, around $6 \%$, on feed conversion; 70 g/day on residual gain; and $17 \%$ on Kleiber rate. The other feed efficiency traits (residual feed intake, partial growth efficiency and relative growth rate) did not differ between herds. The 29-year selection for post-weaning weight did not affect feed efficiency of Nellore cattle.

Key Words: beef cattle, feed conversion, residual feed intake, selection

\section{Eficiência alimentar em bovinos Nelore selecionados para peso pós- desmame}

RESUMO - Foram comparados dois rebanhos Nelore, um selecionado para maior peso pós-desmame e outro controle, selecionado para a média de peso pós-desmame, para avaliar os efeitos de 29 anos de seleção sobre a eficiência alimentar. Sessenta machos Nelore com $205 \mathrm{~kg}$ e 267 dias de idade (41 selecionados e 19 controle), foram avaliados em baias individuais durante a prova de ganho de peso. O desempenho e o consumo de matéria seca foram utilizados para determinar as seguintes medidas de eficiência: conversão alimentar; consumo alimentar residual; ganho residual; eficiência parcial de crescimento; taxa de crescimento relativo; e taxa de Kleiber. Após o período experimental de 112 dias, os animais controle apresentaram menor peso vivo final em comparação aos selecionados, contudo, não diferiram quanto ao consumo de matéria seca (\% do peso vivo), à área de olho-de-lombo e às espessuras de gordura subcutânea na altura da 12aㅡ costela e na região da picanha. O consumo de matéria seca (kg/dia) e o ganho médio diário dos animais selecionados foram, respectivamente, 19,4 e 26,4\% superiores aos dos controle. O maior ganho médio diário dos animais selecionados promoveu melhora significativa, em torno de 6\%, na conversão alimentar; 70 g/dia no ganho residual; e de 17\% na taxa de Kleiber. As demais medidas de eficiência (consumo alimentar residual, eficiência parcial de crescimento e taxa de crescimento relativo) não diferiram entre os rebanhos. Os 29 anos de seleção para peso pós-desmame não afetaram a eficiência alimentar de bovinos Nelore.

Palavras-chave: bovinos de corte, consumo alimentar residual, conversão alimentar, seleção

\section{Introduction}

Beef cattle breeding programs are applied for the selection mainly of growth traits such as weight at different ages, average daily gain and carcass characteristics. A limitation of breeding exclusively for growth would be an indirect selection for increase of adult weight and feed intake, increasing production costs in the growth phase.

Recent studies show that it is possible to obtain more efficient animals, with high weight gain rates, by direct selection. Those animals ingest less feed for the same body weight and the same weight gain, indicating that there is a 
genetic variation of use of nutrients (Herd et al., 2003; Arthur \& Herd, 2008).

Feed conversion in animal products during postweaning growth phase has large influence on meat production costs (Tess \& Kolstad, 2000; Herd et al., 2003). Feed efficiency is very important because a better efficiency may result in smaller grazing area needed for production and, consequently, the environmental pollution (manure and methane) is reduced (Nkrumah et al., 2006), with sustainability of natural resources. The objective of this experiment was to evaluate the effects of selection for postweaning weight on feed efficiency, performance and carcass characteristics of males from the $26^{\text {th }}$ progeny of herds: Control Nellore and Selected Nellore from the breeding project of the Instituto de Zootecnia de Sertãozinho.

\section{Material and Methods}

The experiment was performed at Centro de Pesquisas em Pecuária de Corte, Instituto de Zootecnia, Sertãozinho, SP, Brazil. This region is characterized by a tropical humid climate, with annual average temperature of $24^{\circ} \mathrm{C}$ and average annual precipitation of $1,888 \mathrm{~mm}$.

Cattle herds were assembled in 1933, but in 1976, a restructuration process was started, aiming the selection and the introduction of new lineages to increase genetic variability, in order to avoid high levels of endogamy. In 1980, the following herds were formed: control, which basically did not suffer any genetic change in postweaning weight. For this group, animals were selected based on null selection differential; and selection, which selected animals based on higher selection differential for weight standardized to 378 days of age, obtained in feeding performance tests.

Sixty males were used. Control $(\mathrm{n}=19)$ and selection ( $n=41$ ) herds were from the $26^{\text {th }}$ calf crops of the breeding project, born in 2006, with weight and initial age of $205 \pm 31 \mathrm{~kg}$ and $267 \pm 14$ days, respectively. Animals were kept in individual pens that allowed visual contact among them, with $12.6 \mathrm{~m}^{2}$ of dimension, floor with $4 \mathrm{~m}$ of concrete and $2 \mathrm{~m}$ with compact soil and $4 \mathrm{~m}$ of covering. Feed was supplied in individual troughs with $1.5 \mathrm{~m}$ of length, $0.7 \mathrm{~m}$ of width and $0.5 \mathrm{~m}$ of depth, and water was supplied in lateral water troughs.

Feeding performance test lasted 168 days, until animals reached approximately 378 days of age. Weights were measured at the beginning and in the end of the adaptation period (56 days), and at every 28 days during the collection period (112 days). Animals were submitted to 16 hours of fasting (water and feed) only for the initial and final weightings.

Diet was formulated based on brachiaria grass hay, ground corn, cottonseed meal and mineral supplementation (Table 1).

In order to establish nutritional requirements and diet characteristics, the NRC (2000) level 2 program was used. Samples from the diet ingredients were collected for further analysis of dry matter (DM), crude protein (CP), ether extract (EE), mineral matter (MM), neutral detergent fiber (NDF), acid detergent fiber (ADF), neutral detergent fiber corrected for ash and protein (NDFap) and lignin (Table 2). Analysis were made in Laboratório de Bromatologia do Departamento de Melhoramento e Nutrição Animal of Faculdade de Medicina Veterinária e Zootecnia of Universidade Júlio de Mesquita Filho (FMVZ - UNESP), Botucatu campus.

Animals were supplied twice a day, at 8 a.m. and 3 p.m., with free access to feed and water. Refusals were collected every day, weighted, sampled in $10 \%$ of its weight and adjusted three times per week representing from 5 to $10 \%$ of the total feed offered. Individual voluntary intake was calculated by the difference between offered feed and refusals. Four composed samples of refusals were made for each animal, according to each interval of 28 days for weighting. Feed samples from offered diet were collected from each experimental period.

Samples from offered feed and refusals were dried in a laboratory forced-air oven at $55^{\circ} \mathrm{C}$ for 72 hours, grounded in Willey mills and evaluated for levels of dry matter, crude protein, ether extract, acid detergent fiber and lignin $\left(\mathrm{H}_{2} \mathrm{SO}_{4}\right.$ $72 \% \mathrm{p} / \mathrm{p}$ ), according to procedures described by AOAC (1995). Neutral detergent fiber levels and corrections for ash and protein levels were performed according to Mertens (2002).

Table 1 - Composition of the experimental diet

\begin{tabular}{|c|c|}
\hline Ingredient & \% Dry matter $(\mathrm{DM})$ \\
\hline Brachiaria brizantha hay & 44.90 \\
\hline Ground corn grain & 31.90 \\
\hline Cottonseed meal & 21.50 \\
\hline Mineral supplement ${ }^{1}$ & 1.70 \\
\hline \multicolumn{2}{|l|}{ Nutrient $^{2}$} \\
\hline Dry matter (\%) & 85.98 \\
\hline Crude protein (\% DM) & 10.30 \\
\hline Total digestible nutrients (\% TDN) & 65.00 \\
\hline Net energy of maintenance (Mcal $/ \mathrm{kg}$ ) $\mathrm{DM}^{4}$ & 1.47 \\
\hline Net energy of gain (Mcal/kg DM) & 0.88 \\
\hline Neutral detergent fiber (\% DM) & 50.00 \\
\hline Calcium (\% DM) & 0.62 \\
\hline Phosphorus (\% DM) & 0.48 \\
\hline
\end{tabular}


Table 2 - Nutrient composition of the diet

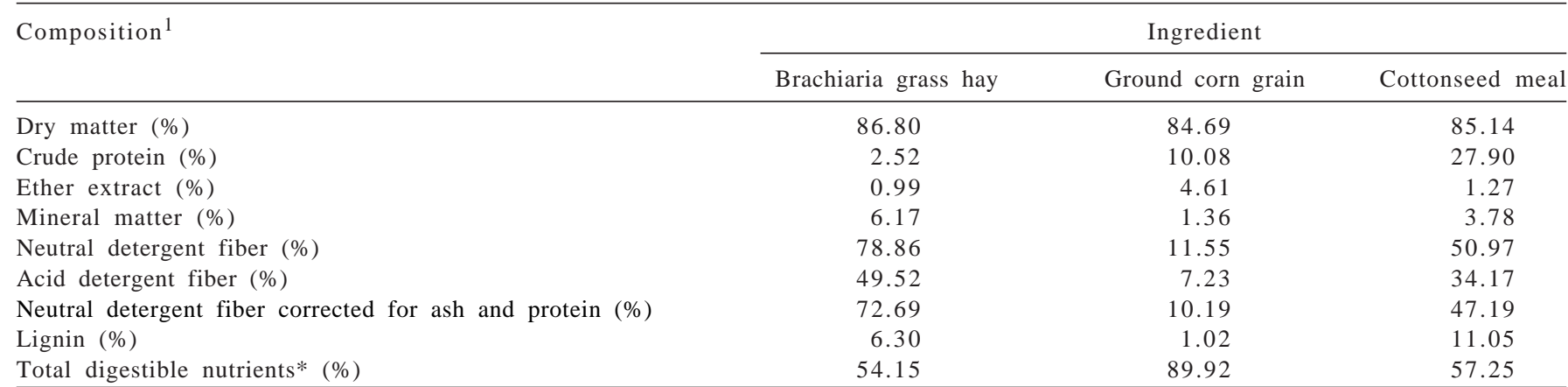

* Values calculated by Weiss equation (Weiss, 1999).

${ }^{1}$ Values expressed as $100 \%$ of dry matter.

Food energy value was estimated according to Weiss (1999) using the following equation: $\mathrm{TDN}=0.98 \times(100-$ NDFap - CP - Ash- EE - 1) + $0.93 \times \mathrm{CP}+2.25 \times \mathrm{EE}+0.75 \times$ (NDFap - lignin) $\times[1$ - (lignin / NDFap)0.667] -7 , in which: $\mathrm{TDN}=$ total digestible nutrients; NDFap = neutral detergent fiber corrected for ash and protein; $\mathrm{CP}=$ crude protein; $\mathrm{EE}=$ ether extract.

Ultrasound technique was used at the beginning and in the end of the experiment to determine rib-eye area (REA), subcutaneous fat thickness on $12^{\text {th }}$ rib (SFT) and fat thickness over biceps femoris (FTR), according to methodology described by Herring et al. (1994). The scanned images were obtained from Piemedical ${ }^{\circledR}$ equipment, Áquila model with linear transducer array with $3.5 \mathrm{MHz}$ of frequency and $18 \mathrm{~cm}$ of length, coupled with a standoff guide for a better adaptation to the anatomy of animal body.

According to Koch et al. (1963), dry matter intake is estimated from regression of daily intake as a function of average metabolic body weight $\left(\mathrm{BW}^{0.75}=[(\mathrm{BWfinal}+\right.$ BWinitial)/2 $]^{0.75}$ ) and average daily gain. Residual feed intake (RFI) was calculated by the difference between observed and estimated intakes.

The following feed efficiency traits were evaluated: feed conversion, partial efficiency of growth (ratio between average daily gain and difference between observed and expected dry matter intake), relative growth rate (percentage of the difference between log of final body weight and initial body weight and the number of days of testing), Kleiber ratio (ratio between average daily gain and metabolic weight), residual feed intake and residual weight gain (difference between observed weight gain and adjusted weight gain by the differences of feed intake and $\mathrm{BW}^{0.75}$ ). In order to determine pre-test environmental effects on measures of performance and efficiency, simple regression equations were calculated between the several characteristics of the test and initial age or initial weight.
The following indices were determined for the 60 animals: IG112 $=($ G112/mG112 $) * 100$, in which IG112 $=$ index of weight gain in 112 days of feedlot; G112 = average weight gain in 112 days of feedlot and mG112 = mean of G112 from racial group; IW378 $=($ W378/mW378 $) * 100$, in which IW378 = index of weight standardized to 378 days; W378 = weight standardized to 378 days and $\mathrm{mW} 378=$ mean of W378 from racial group; and IFPT $=(0.6 * \mathrm{IG} 112)+(0.4 * \mathrm{IW} 378)$, where IFPT $=$ index of feeding performance test.

Animals were classified in six categories, according to IFPT: elite $=$ IFPT $>$ mIFPT $+1 \mathrm{SD}$; superior $=\mathrm{mIFPT}+0.25$ $\mathrm{SD}<\mathrm{IFPT} \leq \mathrm{mIFPT}+1 \mathrm{SD}$; average $=\mathrm{mIFPT}<\mathrm{IFPT} \leq \mathrm{mIFPT}$ $+0.25 \mathrm{SD}$; regular $=$ mIFPT $-0.25 \mathrm{SD}<\mathrm{IFPT} \leq \mathrm{mIFPT}$; ordinary $=$ mIFPT $-1 \mathrm{SD} \leq \mathrm{IFPT}<\mathrm{mIFPT}-0.25 \mathrm{SD}$; inferior: IFPT $<$ IIFPT $-1 \mathrm{SD}$, where: $\mathrm{mIFPT}=$ mean of the index to feeding performance test; SD = standard deviation.

Effects of the selection for postweaning weight and feeding performance test categories on intake, carcass and feed efficiency were analyzed using PROC GLM from SAS (1999) program. The effect of initial age covariate was tested and removed from statistical model when it was not significant $(\mathrm{P}>0.05)$. Interaction between covariate and herd was not significant $(\mathrm{P}>0.05)$ for all evaluated characteristics. Means were adjusted by least squares method, then means from herds were compared by T-test at $5 \%$ of probability and feeding performance test categories were compared by Tukey test at 5\% of probability. Correlations were calculated by multivariate analysis of variance (MANOVA), using herd as fixed effect and initial age as covariate.

\section{Results and Discussion}

Final average body weight was $298 \mathrm{~kg}$, corresponding to an average daily gain of $0.827 \mathrm{~kg} / \mathrm{day}$. The lowest detected variation was from dry matter intake in \% of body weight 
that presented a coefficient of variation (CV) of $6.32 \%$. The highest detected variations were from subcutaneous fat thickness ( $C V=26.63 \%)$ and fat thickness on biceps femoris $(\mathrm{CV}=29.43 \%)$ (Table 3). The coefficients of variation for performance traits were: $12.18 \%$ for average daily gain and $9.59 \%$ for final body weight. These variations are in agreement to the ones reported by MacNeil et al. (1991).

Animals selected for higher postweaning weight presented DM intake, expressed in $\mathrm{kg} /$ day $(\mathrm{P}>0.001)$ and $\mathrm{g} / \mathrm{kg} \mathrm{BW}^{0.75}(\mathrm{P}=0.016)$ higher than control animals. Control animals consumed $19.57 \%$ less feed $(1.1 \mathrm{~kg} /$ day; $\mathrm{P}<0.001)$ than the selected ones, but when dry matter intake needed to achieve the same final weight was evaluated, this classification is inverted. This happened because daily average weight gain of animals from selection Nellore group was $26.75 \%$ higher than control Nellore, and dry matter intake in \% of body weight (2.54 vs $2.56 \% \mathrm{BW}$ ) did not differ $(\mathrm{P}=0.694)$ between herds. Gregory et al. (1994) evaluated the effect of nine different paternal breeds on different efficiency traits and concluded that breeds with higher weight gain rates were more efficient than breeds of lower growth, when assessed in a period of constant weight gain.

The increase of average daily gain, obtained by selection for postweaning weight, provided significant enhance, around $6 \%$ for feed conversion ( $\mathrm{P}=0.047), 70 \mathrm{~g} /$ day for residual gain $(\mathrm{P}=0.002)$ and $16.7 \%$ for Kleiber ratio $(\mathrm{P}=0.011)$. No changes were observed in residual feed intake $(\mathrm{P}=0.189)$ and partial efficiency of growth $(\mathrm{P}=0.816)$ between selected and control animals (Table 3). According to Arthur et al. (2001), feed efficiency traits that gather body weight and average daily gain (partial efficiency of growth and residual feed intake) may identify some variation based on the utilization of feed by the animal, as for growth and for maintenance.

The equation obtained to estimate dry matter intake (DMI) of animals was: DMI $_{\mathrm{p}}=-1.301015+2.300828 \times$ ADG $+0.091755 \times \mathrm{BW}^{0.75}\left(\mathrm{r}^{2}=0.885\right)$, where $\mathrm{ADG}=$ average daily gain; $\mathrm{BW}^{0.75}=$ metabolic body weight. Mean of residual feed intake was $0.00 \pm 0.287 \mathrm{~kg} /$ day, with minimal and maximal values, respectively, $-0.648 \mathrm{~kg} /$ day (most efficient animal) and $+0.694 \mathrm{~kg} /$ day (least efficient animal). Despite standard deviation of residual feed intake had presented low magnitude, $0.287 \mathrm{~kg} /$ day, compared to the results reported for zebu by Almeida et al. (2004), $1.05 \mathrm{~kg} /$ day, this data showed that there is a phenotypic variability for residual feed intake within herds selection Nellore and control Nellore. The difference of observed total amplitude, $1.33 \mathrm{~kg} /$ day, compared to the results found by Almeida et al. (2004), $3.77 \mathrm{~kg} /$ day, may be explained by the fact that animals evaluated in this study were contemporary and extremely homogeneous.

Selected animals, when compared to control ones, presented rib-eye area, estimated by ultrasound at 378 days of average age, significantly higher $\left(59.7\right.$ vs $55.4 \mathrm{~cm}^{2}$; $\mathrm{P}=0.02$ ). No significant differences were observed for subcutaneous fat thickness ( 2.74 vs $2.73 \mathrm{~mm} ; \mathrm{P}=0.940$ ) and fat thickness on rump ( 4.23 vs $4.22 \mathrm{~mm} ; \mathrm{P}=0.969$ ) between selection Nellore and control Nellore groups, respectively. These results are in agreement to the ones reported by Bonilha et al. (2008), who compared selection Nellore and control Nellore herds and reported that the selection for postweaning weight, from 1992 to 2000, determined an increase of approximately $4 \mathrm{~cm}^{2}$ for rib-eye area and did not alter the subcutaneous fat thickness.

Table 3 - Performance, feed intake, carcass characteristics and feed efficiency traits of animals from Nellore selection and control Nellore groups at an average age of 378 days

\begin{tabular}{|c|c|c|c|c|}
\hline & \multicolumn{2}{|c|}{ Nellore } & \multirow[b]{2}{*}{$\mathrm{P}$} & \multirow[b]{2}{*}{$\mathrm{P}_{\operatorname{cov}}{ }^{*}$} \\
\hline & Selection & Control & & \\
\hline Number of animals & 41 & 19 & - & - \\
\hline Final weight (kg) & $316 \mathrm{a} \pm 4.99$ & $257 b \pm 7.19$ & $<0.001$ & 0.017 \\
\hline Average daily gain $(\mathrm{kg})$ & $0.886 \mathrm{a} \pm 0.03$ & $0.699 b \pm 0.02$ & $<0.001$ & 0.963 \\
\hline Dry matter intake (kg/day) & $6.72 \mathrm{a} \pm 0.13$ & $5.62 b \pm 0.18$ & $<0.001$ & 0.146 \\
\hline Rib-eye area $\left(\mathrm{cm}^{2}\right)$ & $59.7 \mathrm{a} \pm 1.39$ & $55.4 \mathrm{~b} \pm 1.89$ & 0.020 & 0.056 \\
\hline Rib fat thickness (mm) & $2.74 a \pm 0.12$ & $2.73 a \pm 0.17$ & 0.940 & 0.388 \\
\hline Fat thickness on rump steak (mm) & $4.23 a \pm 0.22$ & $4.22 \mathrm{a} \pm 0.31$ & 0.969 & 0.988 \\
\hline Feed conversion $(\mathrm{kg} / \mathrm{kg})$ & $7.63 a \pm 0.13$ & $8.09 b \pm 0.19$ & 0.047 & 0.083 \\
\hline Residual feed intake (kg/day) & $-0.033 a \pm 0.04$ & $0.072 \mathrm{a} \pm 0.07$ & 0.189 & 0.502 \\
\hline Residual gain (kg/day) & $0.022 \mathrm{a} \pm 0.01$ & $-0.048 b \pm 0.02$ & 0.002 & 0.480 \\
\hline
\end{tabular}

Means followed by the same letter, in lines, do not differ significantly by T-test at $5 \%$ level of probability.

${ }^{*} P_{\text {cov }}=$ covariate probability initial age. 
When categories grouped according to feeding performance test were studied, average daily weight gain varied significantly $(P=0.001)$ among almost all of them. Average daily gain of Elite category (E - best classification on feeding performance test) was $0.236 \mathrm{~kg} /$ day above overall mean and $0.383 \mathrm{~kg} /$ day higher than Inferior category (I - worst classification on feeding performance test) (Table 4). This variation in average daily gain reinforces the importance of identification and selection of animals with high potential for growth.

Dry matter intake (kg/day) of animals from categories Elite and Superior were significantly higher $(\mathrm{P}<0.001)$ than animals from categories Ordinary and Inferior. Dry matter intake determined in \% body weight, did not differ $(\mathrm{P}=0.425)$ among animals from all categories. Feed intake characteristics presented the same tendency observed when selection Nellore and control Nellore herds were compared, thus there was alteration of intake as a function of the increase of body weight and as a function of metabolic weight of the animals.

Correlations found in this work were consistent to the ones reported in literature (Schenkel et al., 2004; Nkurumah et al., 2004), evidencing that average daily gain and body weight are variables that influence the intake by the animal. According to Tedeschi et al. (2006) cattle that have genetic potential for faster growth, at the same growth stage, are the ones that consume more food in order to satisfy the increases on nutrient requirement.

Significant differences were detected for feed conversion ( $\mathrm{P}=0.033$ ), residual gain $(\mathrm{P}<0.001)$, relative growth rate $(\mathrm{P}=0.028)$ and Kleiber ratio $(\mathrm{P}<0.001)$ among categories of the feeding performance test. The enhance of efficiency traits is strongly associated to the increase of average daily gain promoted by selection (Table 5), which can be proved by significant correlation between average daily gain and feed conversion ( $r=-0.53$ ); $\mathrm{P}<0.001$ ); average daily gain

Table 4 - Performance, feed intake, carcass characteristics and feed efficiency of Nellore animals assorted in categories of feeding performance test

\begin{tabular}{|c|c|c|c|c|c|c|c|c|}
\hline \multirow[t]{2}{*}{ Trait } & \multicolumn{6}{|c|}{ Category } & \multirow[b]{2}{*}{ EP } & \multirow[b]{2}{*}{$\mathrm{P}$} \\
\hline & Elite & Superior & Average & Regular & Ordinary & Inferior & & \\
\hline Number of animals & 6 & 10 & 5 & 5 & 18 & 16 & -- & -- \\
\hline Average daily weight gain (kg/day) & $1.063 \mathrm{a}$ & $0.935 b$ & $0.905 b$ & $0.845 b c$ & $0.792 \mathrm{c}$ & $0.680 \mathrm{~d}$ & 0.068 & $<.0001$ \\
\hline Initial body weight (kg) & $218 a$ & $231 \mathrm{a}$ & 208ab & 211ab & $208 a$ & 178b & 25.5 & $<.0001$ \\
\hline Final body weight (kg) & $338 \mathrm{a}$ & $335 a$ & 309ab & 306ab & 296b & $254 \mathrm{c}$ & 25.9 & $<.0001$ \\
\hline Dry matter intake (kg/day) & $7.35 \mathrm{a}$ & $7.23 a$ & $6.64 \mathrm{ab}$ & $6.35 \mathrm{abc}$ & $6.26 \mathrm{bc}$ & $5.51 \mathrm{c}$ & 0.58 & $<.0001$ \\
\hline Dry matter intake $\left(\mathrm{g} / \mathrm{kg} \mathrm{BW}^{0.75}\right)$ & $107 \mathrm{a}$ & $106 a$ & $104 a b$ & 99ab & $100 \mathrm{ab}$ & $97 b$ & 5.65 & $<.0001$ \\
\hline Dry matter intake (\% BW) & $2.65 a$ & $2.58 \mathrm{a}$ & $2.59 a$ & $2.47 \mathrm{a}$ & $2.51 \mathrm{a}$ & $2.53 \mathrm{a}$ & 0.16 & 0.425 \\
\hline Feed conversion $(\mathrm{kg} / \mathrm{kg})$ & $6.8 \mathrm{a}$ & $7.8 \mathrm{ab}$ & $7.4 \mathrm{ab}$ & 7.5ab & $8.0 \mathrm{ab}$ & $8.1 \mathrm{~b}$ & 0.8 & 0.033 \\
\hline Residual feed intake (kg/day) & $-0.078 a$ & $0.095 a$ & $-0.015 a$ & $-0.202 a$ & $-0.009 a$ & $-0.047 a$ & 0.299 & 0.458 \\
\hline Residual gain (kg/day) & $0.119 a$ & $0.003 \mathrm{~b}$ & $0.034 \mathrm{ab}$ & $0.039 \mathrm{ab}$ & $-0.020 b$ & $-0.047 b$ & 0.079 & $<.0001$ \\
\hline Growth partial efficiency (kg/kg) & $0.328 a$ & $0.298 \mathrm{a}$ & $0.319 \mathrm{a}$ & $0.339 a$ & $0.316 a$ & $0.328 \mathrm{a}$ & 0.054 & 0.591 \\
\hline Relative growth rate $(\mathrm{kg} / \mathrm{dia})$ & $0.168 \mathrm{a}$ & $0.148 \mathrm{ab}$ & $0.157 \mathrm{ab}$ & $0.145 \mathrm{ab}$ & $0.141 b$ & $0.137 b$ & 0.029 & 0.028 \\
\hline Kleiber ratio $(\mathrm{kg} / \mathrm{kg})$ & $0.0156 a$ & $0.0137 \mathrm{abc}$ & $0.0142 \mathrm{ab}$ & $0.0132 \mathrm{abc}$ & $0.0128 \mathrm{bc}$ & $0.0120 \mathrm{c}$ & 0.0015 & $<.0001$ \\
\hline
\end{tabular}

Means followed by the same letter, in lines, do not differ significantly by Tukey test at $5 \%$ level of probability.

Table 5 - Pearson correlations among growth, feed intake, carcass and feed efficiency traits of Nellore cattle

\begin{tabular}{|c|c|c|c|c|c|c|}
\hline Trait & $\begin{array}{c}\text { Feed } \\
\text { conversion }\end{array}$ & $\begin{array}{l}\text { Residual } \\
\text { feed intake }\end{array}$ & $\begin{array}{l}\text { Residual } \\
\text { gain }\end{array}$ & $\begin{array}{c}\text { Partial efficiency } \\
\text { of growth }\end{array}$ & $\begin{array}{l}\text { Relative } \\
\text { growth rate }\end{array}$ & $\begin{array}{l}\text { Kleiber } \\
\text { ratio }\end{array}$ \\
\hline Initial body weight $(\mathrm{kg})$ & $0.65 * * *$ & $0.14^{\mathrm{NS}}$ & $-0.45 * * *$ & $-0.56 * * *$ & $-0.68 * * *$ & $-0.53 * * *$ \\
\hline Average daily gain (kg) & $-0.53 * * *$ & $0.15^{\mathrm{NS}}$ & $0.52 * * *$ & $-0.12^{N S}$ & $0.66 * * *$ & $0.79 * * *$ \\
\hline Dry matter intake (kg/day) & $0.34 * * *$ & $0.58 * *$ & $-0.32 * *$ & $-0.77 * * *$ & $-0.10^{\mathrm{NS}}$ & $-0.07^{\mathrm{NS}}$ \\
\hline Dry matter intake $\left(\mathrm{g} / \mathrm{kg} \mathrm{BW}^{0.75}\right)$ & $-0.07^{\mathrm{NS}}$ & $0.80 * * *$ & $-0.13^{\mathrm{NS}}$ & $-0.65 * * *$ & $0.50 * * *$ & $0.58 * * *$ \\
\hline Dry matter intake (\% BW) & $-0.30 *$ & $0.72 * * *$ & $0.02^{\mathrm{NS}}$ & $-0.39 *$ & $0.72 * * *$ & $0.73 * * *$ \\
\hline Rib-eye area $(\mathrm{cm})$ & $0.2^{\mathrm{NS}}$ & $0.05^{\mathrm{NS}}$ & $-0.12^{\mathrm{NS}}$ & $-0.26 *$ & $-0.25^{\mathrm{NS}}$ & $-0.15^{N S}$ \\
\hline Subcutaneous fat thickness (mm) & $0.30 *$ & $0.26^{\mathrm{NS}}$ & $-0.30 *$ & $-0.39 * *$ & $-0.20^{\mathrm{NS}}$ & $-0.15^{N S}$ \\
\hline Rump fat thickness (mm) & $0.15^{\mathrm{NS}}$ & $0.06^{\mathrm{NS}}$ & $-0.06^{\mathrm{NS}}$ & $-0.20^{\mathrm{NS}}$ & $-0.13^{\mathrm{NS}}$ & $-0.06^{\mathrm{NS}}$ \\
\hline Feed conversion (kg/kg) & - & $0.42 * * *$ & $-0.93 * * *$ & $-0.68 * * *$ & $-0.86 * * *$ & $-0.85 * * *$ \\
\hline Residual feed intake (kg/day) & & - & $-0.66 * * *$ & $-0.84 * * *$ & $0.05^{\mathrm{NS}}$ & $0.08^{\mathrm{NS}}$ \\
\hline Residual gain (kg/day) & & & - & $0.75 * * *$ & $0.68 * * *$ & $0.69 * * *$ \\
\hline Partial efficiency of growth (kg/kg) & & & & - & $0.30 *$ & $0.22^{\mathrm{NS}}$ \\
\hline Relative growth rate (kg/day) & & & & & - & $0.98 * * *$ \\
\hline Kleiber ratio (kg/kg) & & & & & & - \\
\hline
\end{tabular}

$*=\mathrm{P}<0.05 ; * *=\mathrm{P}<0.01 ; * * *=\mathrm{P}<0.001 ; \mathrm{NS}=$ not-significant. 
and residual gain $(\mathrm{r}=0.52 ; \mathrm{P}<0.001)$; average daily gain and relative growth rate $(\mathrm{r}=0.66 ; \mathrm{P}<0.001)$; and average daily gain and Kleiber ratio $(\mathrm{r}=0.79$; $\mathrm{P}<0.001)$. No significant differences were detected for residual feed intake $(\mathrm{P}=0.458)$ and partial efficiency of growth $(\mathrm{P}=0.591)$ among categories of the feeding performance test.

Koch et al. (2004) conducted an experiment involving breeding between selection and control herds with the objective of separating maternal and direct additive genetic responses for 20 years of selection for postweaning weight, weight at one year of age, index of weight at one year of age and muscling score. After a constant interval of time, selection herds gained more weight, consumed more metabolizable energy (ME) and presented better conversion of weight gain/ ME than control herd. This information is in accordance to the ones found in this work, whereas animals were selected through indices which considered weight gain, enhancing performance traits as well as feed conversion traits.

Residual feed intake and partial efficiency of growth presented controversial effect compared to the other efficiency traits and they did not correlate $(\mathrm{P}>0.05)$ to average daily gain, but they significantly correlated to dry matter intake $0.58(\mathrm{P}<0.01)$ and $-0.77(\mathrm{P}<0.001)$, respectively.

Arthur et al. (2001a) did not find phenotypical correlations between residual feed intake and average daily gain, but they reported significant low phenotypical correlations between partial efficiency of growth and average daily gain $(r=-0.14)$. Those authors also reported that residual feed intake was correlated to dry matter intake $(\mathrm{r}=0.60)$, however, the correlation between residual feed intake and dry matter intake did not explain the variability in residual feed intake. According to Tedeschi et al. (2006), residual feed intake represents the residual from an analysis of multiple regression and all contents of variation are not considered (ex.: gain energy content, differences of energy use for fat and protein production, feed digestibility, compensatory growth, protein turnover) by the variable used in the regression equation.

Significant correlation between dry matter intake (\%BW) and residual feed intake $(\mathrm{r}=0.72 ; \mathrm{P}<0.001)$ may be associated to the correction of intake as a function of animal weight when calculating both characteristics. Dry matter intake (\% BW) significantly correlated with other efficiency traits, except for residual gain $(\mathrm{P}>0.05)$.

Several researches that compare animals, or groups of animals, consider feed intake and production over a reduced part of the productive cycle (Archer et al., 1999). Thus feed efficiency is expressed as an index that combine feed intake (input) with production (output). Feed intake and performance, when isolated studied, supply little or any indication of the efficiency of production, because feed efficiency of the system depends on inputs of feed and outputs of production in several animal categories. There are unnumbered indices to describe feed efficiency of animals, each one weighing biological differences and mathematical aspects of efficiency (Archer et al., 1999).

Initial body weight variation of animals was significant ( $\mathrm{P}<0.001)$ and corresponded to $14.9 \%$ of average daily gain, $16.2 \%$ of feed conversion, $21.7 \%$ of partial efficiency of growth, $21.9 \%$ of relative growth rate and $8.0 \%$ of Kleiber ratio, but it was not correlated to residual feed intake. For all studied variables, the initial age was not significant. This can be explained for animals are contemporary with a 90-day age difference at most. Non significant correlations between residual feed intake and average daily gain and between residual feed intake and initial body weight also confirmed the non association between characteristics, demonstrating that residual feed intake was the only efficiency trait, among the five evaluated, regardless to body size. In this study, residual feed intake presented significant correlation $(\mathrm{P}<0.001)$ with feed conversion $(\mathrm{r}=0.42)$, residual gain $(r=-0.66)$ and partial efficiency of growth $(r=-0.84)$, indicating that the inclusion of this trait in breeding programs can promote positive correlated responses in other efficiency traits associated to the decrease of dry matter intake, without altering body size of the animals.

Phenotypical correlations between carcass characteristics (rib-eye area, subcutaneous fat thickness and fat thickness over rump) and residual feed intake were not significant either. Among evaluated efficiency traits, only partial efficiency of growth, residual gain and feed conversion kept correlations with carcass characteristics (Table 5). Partial efficiency of growth is a characteristic calculated by the ratio between average daily gain and the difference of dry matter intake observed and estimated for maintenance. Thus, negative correlations between partial efficiency of growth and carcass characteristics (rib-eye area and subcutaneous fat thickness) can be explained by the increase of dry matter intake correlated to the increase of rib-eye area $(\mathrm{r}=0.44 ; \mathrm{P}<0.001)$ or subcutaneous fat thickness $(\mathrm{r}=0.40 ; \mathrm{P}=0.002)$. Feed conversion and residual gain were correlated only to subcutaneous fat thickness, with values of $0.30(\mathrm{P}<0.05)$ and $-0.30(\mathrm{P}<0.05)$, respectively.

Net energy used for weight gain is known to be the energy content deposited into the tissue, and it is calculated as a function of fat and protein proportion present in tissue gain of empty body. According to Garrett et al. (1959), fat portion represents $9,367 \mathrm{kcal} / \mathrm{g}$ and non-fat organic matter 
content around 5,686 kcal/g. Therefore, higher fat deposition increases energy requirement per unit of weight gain, and the increase of energy requirement decrease the utilization efficiency of the energy consumed, which worsens the characteristics of partial efficiency of growth, feed conversion and residual gain.

Three selection indices evaluated in this study (IG112, IW378 and IFPT) were correlated $(\mathrm{P}<0.001)$ to average daily gain, final body weight and among them (Table 6). This correlation occurred as a function of the traits used to establish the indices that use weight gain (IG112), weight (IW378) or the ponderation of both (IFPT). IG112 was not correlated to initial body weight $(\mathrm{P}=0.47)$. As the involvement of W378 in the index calculation increases, the observed correlation with initial body weight also increases, 0.663 (IP378; $\mathrm{P}<0.001$ ) and 0.294 (IPGP; $\mathrm{P}<0.05$ ), because $\mathrm{W} 378$ is calculated from weight at weaning.

IW378 was the only index that was not correlated $(\mathrm{P}=0.46)$ to $\mathrm{DM}$ intake (in \%BW), because it is composed exclusively by the ordering of weight standardized to 378 days of age, which is the selection criterion of the breeding project of Instituto de Zootecnia, restating the results found between selection Nellore and control Nellore, since no significant differences were detected in the dry matter intake in \%BW, where IG112 = index of weight gain in 112 days of feedlot index of weight standardized to 378 days

Significant correlation found between dry matter intake and the indices was higher for index of weight standardized to 378 days (IW378) $(\mathrm{r}=0.816 ; \mathrm{P}<0.001)$, intermediary for index of feeding performance test (IFPT) $(\mathrm{r}=0.715 ; \mathrm{P}<0.001)$ and lower for index of weight gain in 112 days of feedlot (IG112) $(r=0.600 ; \mathrm{P}<0.001)$. The difference between the coefficients of correlation may be associated to the involvement of body weight in the calculation of the index, therefore the higher the animal weight, the higher the feed intake needed to meet its maintenance requirement.

The decrease of DM intake (in \%BW) as the initial body weight increase can be explained by the association of weight at weaning with the milk production of the dam, because roughage intake per unit of body weight before weaning is consistently higher for calves that receive lower amount of milk (Le Du et al., 1976; Broader et al., 1989).

In general, residual feed intake traits and partial efficiency of growth were not correlated to the indices, except for the significant correlation detected between partial efficiency of growth and IW378 ( $\mathrm{r}=-0.381 ; \mathrm{P}=0.003)$. A possible explanation would be the relation between higher body weight and higher IW378, because the partial efficiency of growth have negative correlation, with initial body weight $(\mathrm{r}=-0.560 ; \mathrm{P}<0.001)$ as well as with final body weight $(\mathrm{r}=-0.542 ; \mathrm{P}<0.001)$.

As the participation of average daily gain in the index increases, the correlation with the other efficiency traits also increases (Table 6). Kleiber ratio is the trait with the strongest correlation with average daily gain $(\mathrm{r}=0.786$; $\mathrm{P}<0.001$ ), and presented coefficients of correlation with indices that were higher than feed conversion, residual gain and relative growth rate.

Results from this study are in accordance to the ones reported by Brown \& Frahm (1975), who also observed effective enhancement in feed conversion when weight gain was used as selection criterion instead of body weight. Phenotypical correlations among indices and traits of performance, intake and feed efficiency suggested that the

Table 6 - Pearson correlation between selection indices and traits of performance, intake and efficiency of Nellore cattle at an average age of 378 days

\begin{tabular}{|c|c|c|c|}
\hline \multirow[b]{2}{*}{ Trait } & \multicolumn{3}{|c|}{ Índex } \\
\hline & IG112 & IW378 & IFPT \\
\hline Average daily gain (kg) & $1.000 * * *$ & $0.706 * * *$ & $0.971 * * *$ \\
\hline Initial weight (kg) & 0.096 NS & $0.663 * * *$ & $0.294 *$ \\
\hline Final weight (kg) & $0.478 * * *$ & $0.864 * * *$ & $0.642 * * *$ \\
\hline Dry matter intake (kg/day) & $0.600 * * *$ & $0.816 * * *$ & $0.715 * * *$ \\
\hline Dry matter intake $\left(\mathrm{g} / \mathrm{BW}^{0.75}\right)$ & $0.689 * * *$ & $0.440 * * *$ & $0.654 * * *$ \\
\hline Dry matter intake (\% BW) & $0.560 * * *$ & -0.099 NS & $0.444 * * *$ \\
\hline Feed conversion (kg/kg) & $-0.530 * * *$ & 0.036 NS & $-0.377 * *$ \\
\hline Residual feed intake (kg/day) & $0.154^{\mathrm{NS}}$ & $0.142 \mathrm{NS}$ & $0.161 \mathrm{NS}$ \\
\hline Residual gain (kg/day) & $0.516 * * *$ & $0.096^{\mathrm{NS}}$ & $0.411 * *$ \\
\hline Partial efficiency of growth $(\mathrm{kg} / \mathrm{kg})$ & $-0.120^{\mathrm{NS}}$ & $-0.381 * *$ & -0.217 NS \\
\hline Relative growth rate (kg/day) & $0.656 * * *$ & 0.004 NS & $0.492 * * *$ \\
\hline Kleiber ratio $(\mathrm{kg} / \mathrm{kg})$ & $0.785 * * *$ & $0.180^{\mathrm{NS}}$ & $0.637 * * *$ \\
\hline IG112 & - & $0.706 * * *$ & $0.971 * * *$ \\
\hline IW378 & - & - & $0.855 * * *$ \\
\hline
\end{tabular}

${ }^{1}$ IG112 = index of average weight gain in 112 days of feedlot; IW378 = index of weight standardized at 378 days of age; IFPT = index of feeding performance test. $*=\mathrm{P}<0.05 ; * *=\mathrm{P}<0.01 ; * * *=\mathrm{P}<0.001 ; \mathrm{NS}=$ not-significant. 
feeding performance test index, when compared to index of weight gain in 112 days of feedlot (IG112) and to index of weight standardized to 378 days (IW378), was the most balanced index to enhance both performance characteristics and feed conversion during postweaning growth phase.

\section{Conclusions}

Selection for postweaning growth performed in Nellore herds from Instituto de Zootecnia does not interfere on feed efficiency of animals and enhances performance traits, without changes on fat deposition and dry matter intake determined according to body weight.

\section{References}

ALMEIDA, R.; LANNA, D.P.; LEME, P.R. Consumo alimentar residual: um novo parâmetro para avaliar a eficiência alimentar de bovinos de corte. In: REUNIÃO ANUAL DA SOCIEDADE BRASILEIRA DEZOOTECNIA, 41., 2004, Campo Grande. Anais... Campo Grande: Sociedade Brasileira de Zootecnia, 2004. (CD-ROM).

ASSOCIATION OF ANALYTICAL CHEMISTRY - AOAC. Official Methods of Analysis. 16.ed. Arlington: AOAC International, 1995. 1025p.

ARCHER, J.A.; RICHARDSON, E.C.; HERD, R.M. et al. Potential for selection to improve feed efficiency of beef cattle: a review. Australian Journal of Agricultural Research, v.50, p.147-161, 1999.

ARTHUR, P.F.; ARCHER, J.A.; JOHNSTON, D.J. et al. Genetic and phenotypic variance and covariance components for feed intake, feed efficiency, and other postweaning traits in Angus cattle. Journal of Animal Science, v.79, p.2805-2811, 2001.

ARTHUR, P.F.; RENAND, G.; KRAUSS, D. Genetic and phenotypic relationships among different measures of growth and feed efficiency in young Charolais bulls. Livestock Production Science, v.6, p.131-139, 2001a.

ARTHUR, P.F.; HERD, R.M Residual feed intake in beef cattle. Revista Brasileira de Zootecnia, v.37, p.269-279, 2008 (supl. especial).

BONILHA, S.F.M.; TEDESCHI, L.O.; PACKER, I.U. et al. Evaluation of carcass characteristics of Bos indicus and tropically adapted Bos taurus breeds selected for post-weaning weight. Journal of Animal Science, v.86, p.1770-1780, 2008.

BROADER, J.T.; JUDKINS, M.B.; KRYSL, L.J. et al. Forage intake, digestibility and digesta kinetics in calves receiving 30 or $60 \%$ milk reduction and ad libitum hay. Journal of Animal Science, v.67 (Suppl.2), p.208 (Abstr.), 1989.

BROWN, M.A.; FRAHM, R.R. Feed efficiency in mice selected for pre weaning and post weaning growth. Journal of Animal Science, v.41, n-4, p.1002-1007, 1975.

GARRETT, W.N.; MEYER; J.H; LOFGREEN, G.P. The comparative energy requirements of sheep and cattle for maintenance and gain. Journal of Animal Science, v.18, p.528-547, 1959.
GREGORY, K.E.; CUNDIFF, L.V.; KOCH, R.M. et al. Breed effects, dietary energy density effects, and retained heterosis on different measures of gain efficiency in beef cattle. Journal of Animal Science, v.72, p.1138-1154, 1994.

HERD, R.M.; ARCHER, J.A.; ARTHUR, P.F. Reducing the cost of beef production through genetic improvement in residual feed intake: Opportunity and challenges to application. Journal of Animal Science, v.81, n.1, p.9-17, 2003.

HERRING, W.O.; MILLER, D.C.; BERTRAND, J.K. et al. Evaluation of machine, technician, and interpreter effects on ultrasonic measures of backfat and longissimus muscle area in beef cattle. Journal of Animal Science, v.72, p.2216-2226, 1994.

KOCH, R.M.; CUNDIFF, L.V.; GREGORY, K.E. et al. Genetic response to selection for weaning weight or yearling weight or yearling weight and muscle score in Hereford cattle: Efficiency of gain, growth, and carcass characteristics. Journal of Animal Science, v.82, p.668-682, 2004

KOCH, R.M.; SWIGER, L.A.; CHAMBERS, D. et al. Efficiency of feed use in beef cattle. Journal of Animal Science, v.22, n.2, p.486-494, 1963.

LE DU, Y.P.L.; BAKER, R.D.; BARKER, J.M. Milk-fed calves. 2. The effect of length of milk feeding period and milk intake upon herbage intake and performance of grazing calves. Journal Agriculture Science, v.87, p.197, 1976.

MACNEIL, M.D.; BAILEY, D.R.; URICK, H. et al. Heritabilities and genetic correlations for postweaning growth and feed intake of beef bulls and steers. Journal of Animal Science, v.69, p3183-3189, 1991

MERTENS, D.R. Gravimetric determination of amylase-treated neutral detergent fiber in feeds with refluxing in beakers or crucibles: collaborative study. Journal of AOAC International, v.85, p.1217-1240, 2002.

NATIONAL RESEARCH COUNCIL - NRC. Nutrient requirements of beef cattle. 7.ed. (UPDATE 2000). Washington National Academy Press. Disponível em <http:// books.nap.edu/readingroom.php?book=beefmodel\&page $=>$ Acesso em: 21/8/2009.

NKRUMAH, J.D.; BASARAB, M.A.; PRICE, E.K. et al. Different measures of energetic efficiency and their phenotypic relationships with growth, feed intake, and ultrasound and carcass merit in hybrid cattle. Journal of Animal Science, v.82, p.2451-2459, 2004.

NKRUMAH, J.D.; OKINE, E.K.; MATHISON, G.W. et al. Relationships of feedlot feed efficiency, performance, and feeding behavior with metabolic rate, methane production, and energy partitioning in beef cattle. Journal of Animal Science, v.85, p.145-153, 2006.

STATISTICAL ANALYSIS SYSTEM - SAS. SAS/STAT user's guide. Cary: Statistical Analysis System Institute, 1999. (CD-ROM).

SCHENKEL, F.S.; MILLER, S.P.; WILTON, J.K. Genetic parameters and breed differences for feed efficiency, growth, and body composition traits of young beef bulls. Journal of Animal Science, v.84, p.177-185, 2004.

TEDESCHI, L.O.; FOX, D.G.; BAKER, M.J. et al. Identifying differences in feed efficiency among group-fed cattle. Journal of Animal Science, v.84, p.767-776, 2006.

TESS, M.W.; KOLSTAD, B.W. Simulation of cow-calf production systems in a range environment: I. Model development. Journal of Animal Science, v.78, p.1159-1169, 2000.

WEISS, W.P. Energy prediction equations for ruminant feeds. IN: CORNELL NUTRITION CONFERENCE FOR FEED MANUfACTURES, 61., 1999, Ithaca. Proceedings... Ithaca: Cornell University, p.176-185, 1999. 